\title{
Measurement of the Underground Economy in Nepal: A
} Currency Demand Approach

\author{
Nirmal Kumar Raut* \\ Namuna Chalise ${ }^{* *}$ \\ Puja Thapa***
}

\begin{abstract}
There have been rising concerns on growing magnitude of Underground Economy in most of the economies irrespective of their state of development. The problem is more apparent in developing economies where legal and institutional arrangements are relatively weaker. This study attempts to estimate empirically the size of Underground Economy in Nepal. We use an indirect method of customized version of Currency Demand Method to measure the same and find that its coverage has been increasing throughout in the last two decades with the most alarming increment in the last two fiscal years 2011and 2012. We attribute these increments particularly to the 1996-2006 armed conflict; the increasing cases of economic and financial crimes; and a large informal sector.
\end{abstract}

Key words: Underground economy, Nepal, currency demand method, economic and financial crimes

JEL Classification: H20; H26

\section{INTRODUCTION}

The size of Underground Economy (UE)is on rise irrespective of the state of development in any economies in the world ${ }^{1}$. The highest human development index (HDI) ranking Scandinavian and various other German speaking countries also exhibited a sizeable increase of their UE during 1960-1995. Similarly, countries with a lower share of UE once also saw a significant increase in recent years such as Switzerland, Austria and the US. As it has been rightly marked by a Business World, a leading business magazine that the "black economy, which quintessentially was the phenomena of the 1970s, is back and booming." This indicates that its size in developing economies have been increasing

\footnotetext{
${ }^{1}$ Underground Economy, shadow economy, parallel economy, and black economy has been used interchangeably in this paper.

${ }^{*}$ Mr. Raut is Lecturer of Economics, Central Department of Economics, Tribhuvan University, Nepal.

${ }^{* *}$ Ms. Chalise is faculty of Economics, Reliance International Academy, Kathmandu.

${ }^{* * *}$ Ms. Thapa is Employee in Nabil Bank, Kathmandu.
} 
at a rate much faster than the developed economies. The estimates made by Schneider and Enste (2002) for IMF reports that the size of the shadow economy in developing countries ranges from 35 to 44 percent of GDP whereas the same for transition and OECD countries ranges from 21 to 30 percent and 14 to 16 percent respectively. In this line, Katsios (2006) mention that more strategic global law enforcement policies are required to combat growing international activities of the shadow economy facilitated by the explosion of free trade and economic integration throughout the world. But this has not been taken seriously by the political leaderships to even conceptualize a comprehensive strategy, let alone start recommending, negotiating, and implementing one.

Various rules and regulations prevail in Nepal to regulate the economic and financial crimes however weak enforcement due to poor institutional capacity has helped further to foster underground economic activities in the recent decades. Although there are no recent studies conducted to estimate the size of black economy in Nepal, indications of its rampant prevalence and its sizeable effect on various fronts mostly the economic one such as higher budgetary and fiscal deficit, increased cost of production among others are apparently noticeable. For example, the scale of money laundering is not known in Nepal but a case can be made for its increasing magnitude due to the informal nature of the economy, predomination of cash transactions, open border with India, unstable political situation and rampant existence of predicate offenses like corruption, bribery, smuggling, human and drug trafficking, use of counterfeit currency, and of late, extortion, looting and arms trading. Many experts on transition and developing countries claim that a large chunk of economic activity, sometimes half or more, is done in shadow which is not recorded in official statistics (Eilat \& Zinnes, 2000). It, therefore, becomes imperative to see if its size in the countries like Nepal has reached to an alarming state so that the Government can take immediate action to prevent its further expansion and reverse the situation. Moreover, the ten years of armed conflict that ended in 2006 with the Comprehensive Peace Agreement (CPA) between Maoist and the Government may also have transformed the dynamics of UE.

This study makes an attempt to estimate empirically the size of UE in Nepal. We use an indirect method of customized version of Currency Demand Method (CDM) to measure the same and find that its coverage has been increasing throughout in the last two decades with the most alarming increment in the last two fiscal years 2011 and 2012. We attribute these increments particularly to the 1996-2006 armed conflict; the increasing cases of economic and financial crimes; and a large informal sector. The unavailability of longer time series data and exclusion of some other relevant policy variables such as for reforms, level of education etc. may render our inferences 
inaccurate. As such, the estimates of UE from this study have to be interpreted with caution and further needs to be verified with other methods of estimation. This study should be taken only as an indicative of the situation of UE in Nepal.

The rest of the paper is structured organized as: the next section presents reviews on the national and international literature available primarily focusing on the approaches these studies used to measure the extent of underground economy in different countries; this section is followed by brief discussion on the legal and institutional arrangements in Nepal that intends to check the growth of UE in Nepal; then in another section we describe data and methodology used to estimate the extent of UE; the section just before the conclusion presents the results of the study and discusses these results; and the last section offers concludes with some possible policy implications.

\section{REVIEW OF LITERATURE}

There is no proper agreement on the definition of UE however one of the broadest definitions refers to it as including all the production of goods and services; either legal or illegal that are deliberately concealed from public authorities. So, not only the illegal activities, but all the legal ones that are untraceable and hence not taxable, and are not reflected in country's National Accounting Systems too are included in UE (Ogunc \& Yilmaz, 2000). Feige (1997) identified four different types of underground economic activities: illegal, unreported, unrecorded, and informal.

Table 1 depicts that unreported income resulted from illegal as well as legal activities; either from monetary, or non-monetary transactions that would generally be taxed were they reported to tax authority are included in UE.

Table 1: Taxonomy of Underground Economic Activities

\begin{tabular}{|c|c|c|c|c|}
\hline & \multicolumn{2}{|l|}{ Monetary Transactions } & \multicolumn{2}{|c|}{ Nonmonetary Transactions } \\
\hline \multirow[t]{2}{*}{$\begin{array}{c}\text { Illegal } \\
\text { Activities }\end{array}$} & \multicolumn{2}{|c|}{$\begin{array}{l}\text { Trade in stolen goods; drug dealing and } \\
\text { manufacturing; prostitution; gambling ; } \\
\text { smuggling and fraud. }\end{array}$} & \multicolumn{2}{|c|}{$\begin{array}{l}\text { Barter: drugs, stolen goods, smuggling, } \\
\text { etc. } \\
\text { Produce or growing drugs for own use. } \\
\text { Theft for own use. }\end{array}$} \\
\hline & Tax Evasion & Tax Avoidance & Tax Evasion & Tax Avoidance \\
\hline $\begin{array}{c}\text { Legal } \\
\text { Activities }\end{array}$ & $\begin{array}{l}\text { Unreported } \\
\text { income from self } \\
\text { employment; } \\
\text { wages, salaries } \\
\text { and assets from } \\
\text { unreported work } \\
\text { related to legal } \\
\text { services and goods. }\end{array}$ & $\begin{array}{l}\text { Employee } \\
\text { discounts fringe } \\
\text { benefits. }\end{array}$ & $\begin{array}{l}\text { Barter of legal } \\
\text { services and } \\
\text { goods. }\end{array}$ & $\begin{array}{l}\text { All do-it- yourself } \\
\text { work and } \\
\text { neighbor help. }\end{array}$ \\
\hline
\end{tabular}

Source: Mirus and Smith (1997). 
Becker (1968) and others suggests that people engage in shadow economic activity for financial/economic gain, and weigh expected gains with expected costs in ways that is not consistent with the predictions of traditional economic theory. On benefit side, for example, there may be a substantial cost advantage that informal companies gain by avoiding taxes and regulations because inefficient informal players stay in business and prevent more productive, formal companies from gaining market share. However, any short-term benefits of informality greatly outweigh its long-term negative impact on economic growth and job creation, for example.

Studies reveal that the main reasons for a rise in shadow economy are: the rise of the burden of taxes and social security contributions; increased regulation in the official economy, especially of labor markets; forced reduction of weekly working time; earlier retirement; and the decline of civic virtue and loyalty towards public institutions combined with a declining tax morale. This therefore requires an interdisciplinary analysis of the determinants of the increase in the shadow economy since economic factors can only partly explain the increase (Schneider \& Enste, 2000). The deepening UE leads towards the reduction of government revenue which may further result to inefficient bureaucracy. But there is an ambiguity about the effect of shadow economy on economic growth of official economy. Studies show both positive and negative relationship between the growth of the shadow economy and the official one. For example, Adam and Ginsburgh (1985) and Asea (1996) discuss on the positive aspects while Schneider and Enste (2000) and Loayaza (1996) talk about the negative side.

Various methods are available to measure the extent of UE broadly categorized into direct and indirect methods. Direct method includes sample survey and tax audit method whereas indirect method includes income-expenditure difference method, national accounts discrepancy method, official - actual labor difference method, transaction approach, CDM, electricity consumption approach and the model approach. More detail on this is available in Schneider and Enste (2000).The model approach also called Dynamic Multiple Indicators Multiple Causes (DYMIMIC) is a recent innovation and is considered to be the most comprehensive in the sense that it considers multiple indicators and multiple causes unlike other methods that focuses on only one aspect or indicator for the existence and growth of shadow economy. It uses a factor-analytic approach to measure the hidden economy as an unobserved variable over time for the estimation.

Studies by Torgler and Schneider (2007) and Dreher and Schneider (2006) use DYMIMIC and CDM method to measure the shadow economy as a percentage of the official GDP. These studies primarily assess how governance or institutional quality and tax morale affect the shadow economy. The study found that the shadow 
economy reduces corruption in high income countries but increases corruption in low income countries. The study also found that stricter are the regulations, more would be size of corruption as well as the shadow economy. Another study by Choi and Thum (2002) shows that the entrepreneur's option to flee to the UE constrains a corrupt official's ability to introduce distortions to the economy for private gains. The unofficial economy mitigates government-induced distortions and, as a result, leads to enhanced economic activities in the official sector. This, therefore, means that the presence of the unofficial sector acts as a complement to the official economy rather than a substitute. Katsios (2006) attempted to highlight the interaction between UE and corruption in Greece and concluded that there is a strong and consistent relationship between the shadow economy and corruption - people who are not willing or cannot bribe central or local government bureaucrats, or those having no connections, systematically choose shadow economy as a substitute for corruption in Greece and thereby making the shadow economy complementary to a "corrupt state". Dutta et al. (2011) empirically justified their hypothesis that higher corruption increases level of informal sector in India using OLS specification.

Porqueras et al. (2011) uses Lagos-Wright theoretic model of money to analyze and derive the estimates of the size of shadow economy and concludes that the size of the shadow economy is endogenously determined and depends on the rate of inflation, the marginal tax rate and the way the tax savings from using cash are split between buyers and sellers. They defined shadow economy in terms of cash transactions done solely to evade tax.

The study of Chaudhary et al. (2006) uses MIMIC (Multiple Indicators Multiple Causes) model to show that after liberalization of the Indian economy in 1991/92, the growth in the size of the hidden economy has decreased on an average. They also offer an empirical investigation to determine the role of socio-economic, political, and institutional factors explaining the size of the hidden economy. The study of Arby et al. (2010) uses the electricity consumption approach and MIMICS models to estimate the size of informal economy in Pakistan. The electricity approach shows that the extent of the unmeasured economy was less 5 percent during 1970s which then increased sharply until 1990s and remained stagnant after that. The results of MIMIC model show that the informal economy has been around 30\% of the total economy in Pakistan, which declined considerably in 2000s. At present, about 20 percent of the economic transactions are taking place in the informal sector in Pakistan.

There have not been many studies conducted to estimate the size of shadow economy in Nepal. The most recent study by Schneider et al. (2010) estimates the size of shadow economy for 162 countries including Nepal. The paper uses MIMIC model and a 
Structural Equation Model (SEM) with one latent variable to estimates the level of shadow economy and found that the average size of shadow economy as a percent of official GDP of Nepal was 36.7 for the period 1999 to 2007. The paper considers tax and social security contribution burdens, intensity of regulations, public sector services, the state of official economy, monetary indicators, and labor market indicators as indicators that reflect the level of shadow economy activities. Studies show that the size of shadow economy in Nepal has grown from 32.6 percent in 1990 to 33.4 percent in 1995 to 36 percent in 2007. Although these estimations show that the size has increased merely by 2.6 percentage points between 1995 and 2007, the recent past in Nepalese economy saw dramatic political changes which are believed to have helped both the capitalist and the working class amass property primarily from tax evasion and money laundering. This must have further increased the share of shadow transaction in the economy.

\section{ASSESSMENT OF NEPALESE LEGAL AND INSTITUTIONAL ARRANGEMENTS}

Revenue policy of the Government of Nepal aims to control revenue leakage by developing investigation process through strictly monitoring market and control of illegal trade, controlled sale of health hazard goods among others. Pyakuryal et al. (2009) indicates that there is a problem in complying with the government's policy announcements due to the absence of prudent policy guideline and that the revenue policy of Nepal is not based on the standard global policy framework which is further influenced by political pressures and product-specific demand from business interest groups. This indicates that our policy instead encourages the growth of UE because of the lack of proper harmonization across policies and weak enforcement of existing laws and regulations.

Various Acts in Nepal (e.g., The Income Tax Act 2002; the VAT Act 1995; Excise Act 2002; Custom Act 2007 etc) have made adequate provisions to punish and penalize the tax evaders but the experience shows that the cases of tax evasion have not reduced. Ghimire (2006) provides more detail on the legal and institutional efforts to curb Underground Economy in Nepal. The view of Rajkarnikar (2006) is that the evasion of duty through undervaluation or mis-description of imports is an acute problem for custom administration in developing countries. In case of Nepal, King et al. (2003) estimated a widespread under invoicing while Filmer (2003) reports the view of trading community that there is a threat at declaring a higher value and delaying clearance to extract illegal payments from the traders. 
The role of the Revenue Leakage (Investigation and Control) Act 1995, after the amendment in 2002, has been confined to investigate the revenue leakages during the collection of revenue. This act has been criticized on the ground that it is unfair and inappropriate to prevent corruption and only few cases of action has been reported under the Act till date. The RID (Revenue Investigation Department) is responsible for investigating and prosecuting cases of revenue pilferage by any person in the sector of customs, excise duties, tax administration for non-payment of customs/excise duties, forging Letters of Credit, stealing motor vehicles and their illicit trafficking etc. One of the major weaknesses of RID from institutional perspective is that the same revenue cadres sometimes are involved in the revenue collection and sometimes they are assigned the role of controlling revenue leakages. This is primarily due to the revenue cadre system preventing transfers of general civil servants to the Ministry of Finance.

There are several other financial crime related Acts and Regulations in Nepal including Commission for Investigation of Abuse of Authority (CIAA) Act 1991 ; Prevention of Corruption Act (POCA) 2002; Muluki Ain; The Trafficking of Human Beings (Control) Act, 1980; The Narcotic Drugs (Control) Act, 1976; Foreign Exchange (Regulation) Act, 1962, Asset (Money) Laundering Act, 2008. So far as the institutional arrangements are concerned, Government Bodies such as Special Police Department, RID and District Administration office and Constitutional Bodies such as CIAA, Special Court, Office of Auditor General and Public Accounts Committee have been established to ensure the effective implementation of these Acts and Policies. The challenge, however, still remain to properly harmonize the institutional arrangements with the legal one and secure reforms in governance and accountability both among service providers and its seekers.

\section{MODEL SPECIFICATION}

The study makes use of secondary sources for data collection. The data required for the estimating the size of UE has been gathered from various sources primarily Quarterly Economic Bulletin of Nepal Rastra Bank (the Central Bank of Nepal), Economic Survey of Ministry of Finance, Government of Nepal, and the World Bank Database. The secondary data is collected for the period 1985-2011 depending upon the availability of data of the variables included in the currency demand equation.

We choose the CDM of indirect method to estimate the size of UE. The CDM can be conveniently applied in the case of Nepal since monetary data are well maintained. This approach was first used by Cagan (1958) for the US over the period 1919 to 1955 and this method was further developed by Tanzi $(1980,1982,1983)$ who econometrically estimated a currency demand function for the US economy. This approach assumes that shadow (or hidden) transactions are undertaken in the form of cash payments, 
so as to leave no observable traces for the authorities. An increase in the size of the shadow economy will therefore increase the demand for currency. Many studies use the CDM to estimate the size of UE so far (See literature review above).

Considering the macroeconomic situation of Nepal, we assume that the demand for money $\left(\mathrm{M}_{\mathrm{t}}\right)$ is generated from tax rates (TAXR $\mathrm{R}_{\mathrm{t}}$ ), income in the "recorded or official" economy $\left(Y_{t}\right)$, the interest rate on saving deposit $\left(R_{t}\right)$, the household final consumption $\left(\mathrm{C}_{\mathrm{t}}\right)$ and the consumer price index $\left(\mathrm{CPI}_{\mathrm{t}}\right)$. In order to postulate the theoretical model, we take Gills (1998) definition as the starting point.

$$
\mathrm{M}_{\mathrm{t}}=\beta_{0}^{\prime} \mathrm{R}_{\mathrm{t}}^{\beta_{1}} \mathrm{Y}_{\mathrm{t}}^{\beta_{2}} \mathrm{CPI}_{\mathrm{t}}^{\beta_{3}} \exp \left(\varepsilon_{\mathrm{t}}\right)
$$

Including tax rates and the household consumption, the model can be re-specified as

$$
\mathrm{M}_{\mathrm{t}}=\beta_{0}^{\prime} \mathrm{C}_{\mathrm{t}}^{\beta_{1}} \mathrm{R}_{\mathrm{t}}^{\beta_{2}} \mathrm{TAXR}_{\mathrm{t}}^{\beta_{3}} \mathrm{Y}_{\mathrm{t}}^{\beta_{4}} \mathrm{CPI}_{\mathrm{t}}^{\beta_{5}} \exp \left(\varepsilon_{\mathrm{t}}\right)
$$

Taking the natural logarithm of the model in (2):

$\ln \mathrm{M}_{\mathrm{t}}=\beta_{0}+\beta_{1} \ln \mathrm{C}_{\mathrm{t}}+\beta_{2} \ln \mathrm{R}_{\mathrm{t}}+\beta_{3} \ln \mathrm{TAXR}_{\mathrm{t}}+\beta_{4} \ln \mathrm{Y}_{\mathrm{t}}+\beta_{5} \ln \mathrm{CPI} \mathrm{t}_{\mathrm{t}}+\varepsilon_{\mathrm{t}}$

Where $\beta_{0}=\ln \left(\beta_{0}\right)$. The error term is assumed to be normally and independently distributed.

We use the CDM approach developed by Tanzi (1983) and further customized by Ariyo and Bekoe (2012) in their study to measure the size of UE in Nigeria - the customized version necessitated to address the problems of unavailability of some data in Tanzi's (1983) version particularly in developing economies.

$$
\begin{aligned}
& \ln \left(\frac{\mathrm{C}}{\mathrm{M}_{2}}\right)_{\mathrm{t}}=\beta_{0}+\beta_{1} \ln \left(\frac{\mathrm{Consm}}{\mathrm{Y}}\right)_{\mathrm{t}}+\beta_{2} \ln \mathrm{R}_{\mathrm{t}}+\beta_{3} \ln \left(\frac{\mathrm{T}}{\mathrm{Y}}\right)+\beta_{4} \ln \left(\frac{\mathrm{Y}}{\mathrm{N}}\right)_{\mathrm{t}}+\beta_{5} \ln I N \mathrm{IF}_{\mathrm{t}}+\mathrm{u}_{\mathrm{t}} \\
& \text { with } \beta_{1}>0, \beta_{2}<0, \beta_{3}>0, \beta_{4}>0
\end{aligned}
$$

Where,

In denotes natural logarithm, C / M2 is the ratio of cash holdings to current and deposit accounts, $\mathrm{T} / \mathrm{Y}$ is the total tax revenue of the government per Gross National Product (GNP) (to proxy changes in the size of the shadow economy), Consm / Y is a proportion of private consumption in national income (to capture changing payment and money holding patterns), $\mathrm{R}$ is the interest paid on savings deposits (to capture the 
opportunity cost of holding cash) and $\mathrm{Y} / \mathrm{N}$ is the per capita income and INF is the rate of inflation (indicating general price level).

Any "excess" increase in currency, or the amount unexplained by the conventional or normal factors (mentioned above) is then attributed to the rising tax burden and the other reasons leading people to work in the shadow economy. Although CDM has many limitations, it has been widely used including in many OECD countries.

It is hypothesized that level of consumption $\left(C_{t}\right)$ would increase the demand for money. The interest rate and the inflation are the opportunity cost for holding money. Higher interest rate on saving deposit would induce people to hold less money in cash whereas at lower interest rate people would like to hold more money in cash. This shows that there is an inverse relationship between the interest rate on saving deposit and the demand for money. On the other hand, the dominant view is that the transaction demand for nominal balances increases as the price level rises. It could also be the case that as the general price level is increasing, money will lose value and rational people will tend to choose holding real assets reducing the demand for money (Asaminew, 2010). Hence, we presume that the sign of CPI is unknown. Accordingly, increasing tax rates would increase the demand for money for underground transactions. So we hypothesize that there is a positive relationship between money demand and the tax rates. Finally, we hypothesize that the demand for money will increase with the increase in the level of income.

The stationarity of the series used in equation (3.a) is statistically tested by applying Augmented Dickey-Fuller (ADF) (Dickey \& Fuller, 1979,1981) tests for unit root. If found non stationary, the non-stationary series is differenced to make it stationary before the equation is estimated. We then further proceed to measure the size of UE by estimating the size of the illegal money, legal money, velocity of money and UE consecutively. To calculate illegal money (IM), we re-estimate the Currency Demand Equation (i.e., Currency-M2 ratio in 3.a) first with tax and then without tax ${ }^{2}$.With tax the equation is specified as:

$$
\Delta \ln \left(\frac{\mathrm{C}}{\mathrm{M}_{2}}\right)_{\mathrm{t}}=\beta_{0}+\beta_{1} \Delta \ln \left(\frac{\mathrm{CONSM}}{\mathrm{Y}}\right)_{\mathrm{t}}+\beta_{2} \Delta \ln (\mathrm{R})_{\mathrm{t}}+\beta_{3} \Delta \ln \left(\frac{\mathrm{T}}{\mathrm{Y}}\right)_{\mathrm{t}}+\mathrm{u}_{\mathrm{t}}
$$

\footnotetext{
${ }^{2}$ In order to estimate (equation 4) with and without tax specifications (equation 5), we discard the variables which were found to be highly insignificant in the full/final specification (3.b) (See below) namely per capita income and inflation. For the estimation result of final specification (3.b), see Appendix 3.
} 
Without the tax the equation is specified as :

$$
\Delta \ln \left(\frac{\mathrm{C}}{\mathrm{M}_{2}}\right)_{\mathrm{t}}=\beta_{0}+\beta_{1} \Delta \ln \left(\frac{\mathrm{CONSM}}{\mathrm{Y}}\right)_{\mathrm{t}}+\beta_{2} \Delta \ln (\mathrm{R})_{\mathrm{t}}+\mathrm{u}_{\mathrm{t}}
$$

IM is then given by difference in result in (4) and (5) multiplied by M2.

$$
\left(\Delta \ln \left(\frac{\mathrm{C}}{\mathrm{M}_{2}}\right)_{\mathrm{t}} \text { with tax }-\Delta \ln \left(\frac{\mathrm{C}}{\mathrm{M}_{2}}\right)_{\mathrm{t}} \text { without tax }\right) * \mathrm{M} 2
$$

Such a value can be calculated for each $t$ by putting the corresponding observed. For legal money, illegal money (IM) is subtracted from Narrow money (M1). Then velocity of money $(\mathrm{V})$ is calculated as GNP/LM. If such velocity $(\mathrm{V})$ is multiplied by IM, the total volume of UE is obtained. We further test the stability of specifications (4) and (5) using CUSUM and CUSUMSQ test. The details on the CUSUM and CUSUMSQ tests are provided in Brown et al. (1975).

\section{RESULT AND DISCUSSION}

We begin the discussion by presenting descriptive analysis related to the variables used in the study.

\section{Descriptive Analysis}

The annual growth rate of revenue fell abruptly to 14.7 percent in 2011 from 25.4 percent in 2010. The populist tax reform measures such as Voluntary Tax announcement introduced by the Maoist Government after signing the CPA with the government in 2006 saw a huge growth in revenue in FY 2009. Later the new governments, in and after 2009 , were not able to sustain the benefits of the reform measures and led to a sharp decline in the growth of the revenue thereafter. This indicates highly unpredictable nature of revenue trend in Nepal particularly depending on policy announcements with its strict enforcement and unconditional compliance (See Table 2).

Table 2: Revenue Status of Government of Nepal (2007 - 2011)

\begin{tabular}{lccccc}
\hline Description & 2007 & 2008 & 2009 & 2010 & 2011 \\
\hline Revenue annual growth (\%) & 21.3 & 22.7 & 33.3 & 25.4 & 14.7 \\
Revenue/GDP (\%) & 12.1 & 13.2 & 14.5 & 15.4 & 15.0 \\
Tax Revenue/GDP (\%) & 9.8 & 10.4 & 11.8 & 13.3 & 12.8 \\
Non Tax Revenue/GDP (\%) & 2.3 & 2.8 & 2.7 & 2.0 & 2.2 \\
\hline
\end{tabular}

Source: MOF, Government of Nepal, 2011. 
Value added tax, Income tax and the Custom duty are the three major sources of tax revenue in Nepal in the recent years contributing respectively 36 percent, 24 percent and 21 percent of total tax revenue (MOF, 2011). In earlier years, the custom duty was the largest source of revenue which continued till 2001 followed by VAT/Sales Tax and other sources of revenue (See Figure 1). But after 2001, the economy saw a gradual increase in the VAT revenue and it became the largest source of revenue thereafter. The most important reasons being the introduction of VAT as a multi-stage tax in 1995 (as a substitute to Sales Tax) and a gradual reduction of tariff and non-tariff barriers to meet SAFTA and WTO obligations. Nepalese economy adopted various measures of external and internal liberalization after 1990s when multiparty democracy was restored in Nepal however their effects particularly of external liberalization was noticeable only after 2001. The economic distortions and political disturbances in the 1990s are basically responsible for the lagged/delayed effect of the various economic reform measures initiated during the period.

Figure 1: Trends of Various Types of Tax Revenue (1991-2011) ${ }^{3}$

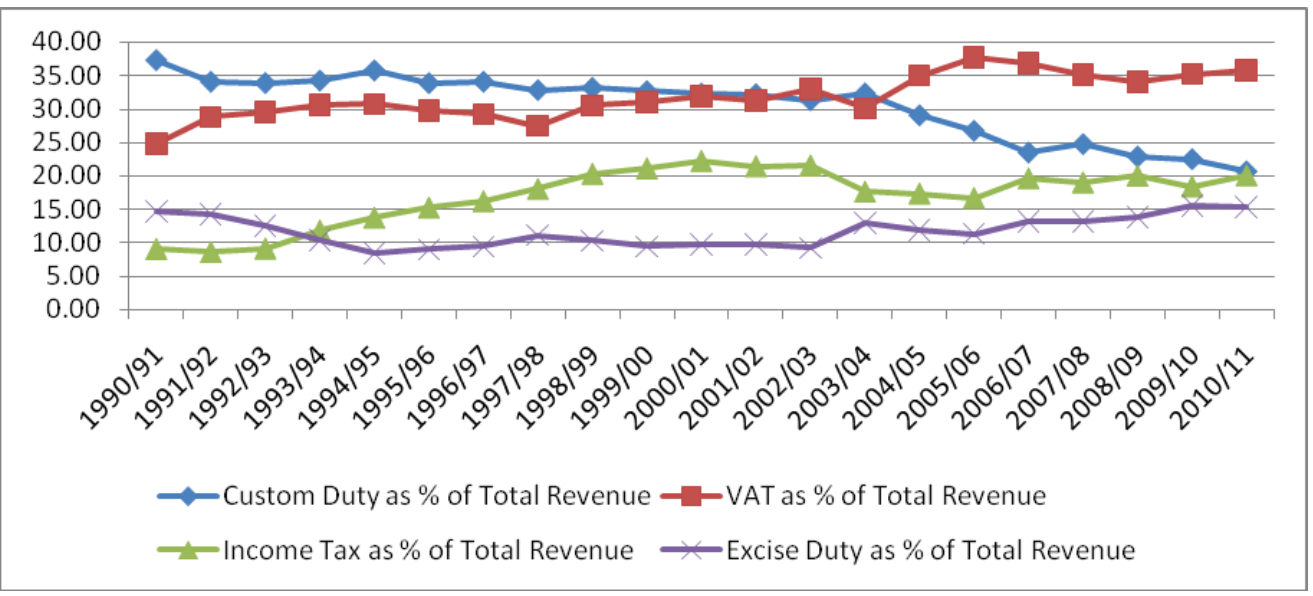

Source: MOF, Government of Nepal, 2011

As a consequence, the trend in the average growth rate of various sources of tax revenue exhibit a surprising change particularly after 2001 for example, the average growth rate of all major taxes except for excise duties has actually declined after 2001. So far as excise duty is concerned, its contribution to total revenue has declined in recent years but it has been contributing at a rate higher than other important revenue sources (See Table 3).

${ }^{3}$ Nepali fiscal year starts from July. For all figure purposes, please read for e.g. FY 1990/91 as 1991, FY 1991/92 as 1992 and so on. 
Table 3: Growth Rate of Various Types of Tax Revenue, 1991-2001 and 2002 - 2011

\begin{tabular}{lcc}
\hline Sources of Tax Revenue & $\mathbf{1 9 9 1 - 2 0 0 1}$ & $\mathbf{2 0 0 2 - 2 0 1 1}$ \\
\hline Custom Duty & 15.63 & 11.71 \\
Sales Tax/VAT & 20.44 & 18.00 \\
Excise Duty & 12.42 & 23.69 \\
Income Tax & 28.69 & 16.08 \\
Total & 17.11 & 16.65 \\
\hline
\end{tabular}

Source: MOF, Government of Nepal, 2011

Besides the lagged effect of various reform measures initiated particularly in the 1990s, the presence of parallel UE may also have increased thereby explaining such an unusual change in the growth pattern of various sources of revenue in the last two decades. Several studies show that the most important effect of the existence of UE is the loss of government revenue. Furthermore, informal economy itself occupies $35 \%$ to 50\% of the total economic transactions (GDP) in Nepal which implies that the total share of unobserved economy should be much higher since this will also include the illegal transactions/activities such as arms trading, smuggling, sex works etc. The focus of this study is to reveal the extent of UE however more precise estimation would require a different investigative approach in order to track and measure the magnitude of the illegal transactions/activities.

\section{Analysis of Empirical Results}

The results of Augmented Dickey-fuller (ADF) tests show that all the variables are stationary at the first difference except for consumption per GNP (CONSM/Y) and the income per capita $(\mathrm{Y} / \mathrm{N})$. The CONSM/Y is stationary at the levels whereas the $\mathrm{Y} / \mathrm{N}$ is stationary only at second difference (See Appendix 2). The mixed result of stationarity test does not allow us to run co-integration test (Johansen, 1988; Johansen \& Juselius, 1990) as well as to apply Autoregressive Distributed Lag Model (ARDL)/Bounds Testing (Pesaran \& Shin, 1999; Pesaran et al., 2001) to see if there are either a short run or a long run equilibrium relationship between the variables. The ARDL methodology is appropriate only when variables are stationary either at levels or at first differences. Moreover, imposing lags of appropriate length in the ARDL specification would remarkably limit our number of observations when we are already working with limited number of time series information. We therefore re-specify our model based on the test of stationarity as follows:

\footnotetext{
${ }^{4}$ Specification issues primarily from serial correlation due to "feedback effect" should not be a problem here as shown by the results from DW test and the LM test. The only limitation of the study is its inability to address the issue of reverse causality however we believe this does not pose a serious threat to the objective of estimating the extent of UE in the study.
} 


$$
\Delta \ln \left(\frac{\mathrm{C}}{\mathrm{M}_{2}}\right)_{\mathrm{t}}=\beta_{0}+\beta_{1} \ln \left(\frac{\mathrm{CONSM}}{\mathrm{Y}}\right)_{\mathrm{t}}+\beta_{2} \Delta \ln (\mathrm{R})_{\mathrm{t}}+\beta_{3} \Delta \ln \left(\frac{\mathrm{T}}{\mathrm{Y}}\right)_{\mathrm{t}}+\beta_{4} \Delta\left(\Delta \ln \left(\frac{\mathrm{Y}}{\mathrm{N}}\right)_{\mathrm{t}}\right)+\beta_{5} \Delta \ln \mathrm{INF}_{\mathrm{t}}+\mathrm{u}_{\mathrm{t}}
$$

For the calculation of Illegal Money (IM), we need to estimate two different equations with and without tax separately. We excluded $\mathrm{Y} / \mathrm{N}$ and INF variables from these two specifications (equations 4 and 5) since they were highly insignificant in full specification (3.b) (See Appendix 3).The empirical results are summarized in Table 4.

Table 4: OLS Result With and Without Tax

\begin{tabular}{|c|c|c|c|c|c|c|}
\hline \multirow{2}{*}{ Variable } & \multicolumn{3}{|c|}{ With Tax } & \multicolumn{3}{|c|}{ Without Tax } \\
\hline & Coefficient & t-Stat & p-value & Coefficient & $\mathrm{t}-$ Stat & $\mathrm{p}$-value \\
\hline Constant & $0.1887^{*}$ & 2.3679 & 0.027 & $0.1692^{*}$ & 2.1389 & 0.043 \\
\hline $\ln (\mathrm{CONSM} / \mathrm{Y})$ & $0.8692^{* *}$ & 2.7714 & 0.011 & $0.7717^{*}$ & 2.5088 & 0.02 \\
\hline$\Delta \ln (\mathrm{T} / \mathrm{Y})$ & 0.1908 & 1.2539 & 0.223 & & & \\
\hline$\Delta \ln (\mathrm{R})$ & $-0.1695^{* *}$ & -3.6249 & 0.002 & $-0.1718^{* *}$ & -3.6317 & 0.001 \\
\hline \multicolumn{4}{|c|}{ R-squared $=0.49$} & \multicolumn{3}{|c|}{ R-squared $=0.45$} \\
\hline \multicolumn{4}{|c|}{ Adjusted R-squared $=0.42$} & \multicolumn{3}{|c|}{ Adjusted R-squared $=0.40$} \\
\hline \multicolumn{4}{|c|}{ F-statistic $=6.95$} & \multicolumn{3}{|c|}{ F-statistic $=9.40$} \\
\hline \multicolumn{4}{|c|}{$\operatorname{Prob}($ F-statistic $)=0.002$} & \multirow{2}{*}{\multicolumn{3}{|c|}{$\begin{array}{l}\text { Prob }(\text { F-statistic })=0.001 \\
\text { Durbin-Watson stat }=2.42\end{array}$}} \\
\hline \multicolumn{4}{|c|}{ Durbin-Watson stat $=2.39$} & & & \\
\hline
\end{tabular}

* Significant at $5 \%$ level of significance, ${ }^{* *}$ significant at $1 \%$ level of significance

The sign of all the coefficients are as expected, that is, consumption per GNP and tax revenue per GNP positively affects C/M2 whereas interest rate affects negatively. All the coefficients are significant at 5 percent and 1 percent level of significance. However, the coefficient of $\mathrm{T} / \mathrm{Y}$ is marginally insignificant. Since sign is as expected and $\mathrm{t}$-stat is 1.25 , we can argue that the longer series may be able to show strong relationship.

Both the Lagrange Multiplier (LM) test for the serial correlation of residuals and the CUSUM and CUSUSMSQ test of recursive residuals show that the models are stable. LM test shows that there is no serial correlation in residuals of the both fitted models with the F-stat 1.05 and p-value 0.43 for equation 4 and F-stat 1.12 and p-value 0.40 for equation 5. Similarly, both the CUSUM and CUSUMSQ lie within the 5 percent significance range (See Appendix 1).

Except for some fiscal years, we observe that the growth rate of IM is always higher than the LM (See Figure 2). Since the value of UE is dependent on the IM and its velocity, we can also infer that the UE is on rise in Nepal irrespective of the fact that the 
multiple reform measures were introduced and rules and regulations enacted during the period (See Figure 3).

Figure 2: Growth Rate of Legal and Illegal Money (1987-2012)

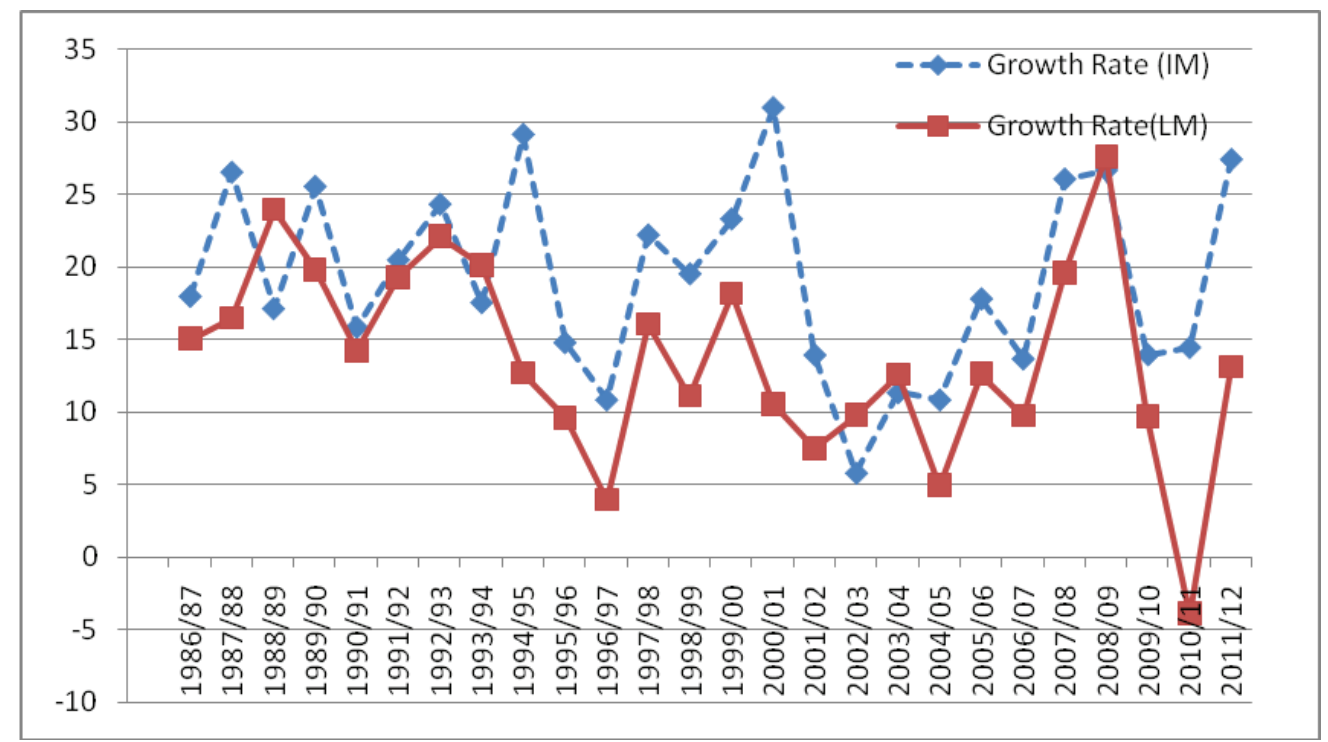

Source: Author's estimation.

Figure 3: Underground Economy as a Percentage of GNP (1986-2012)

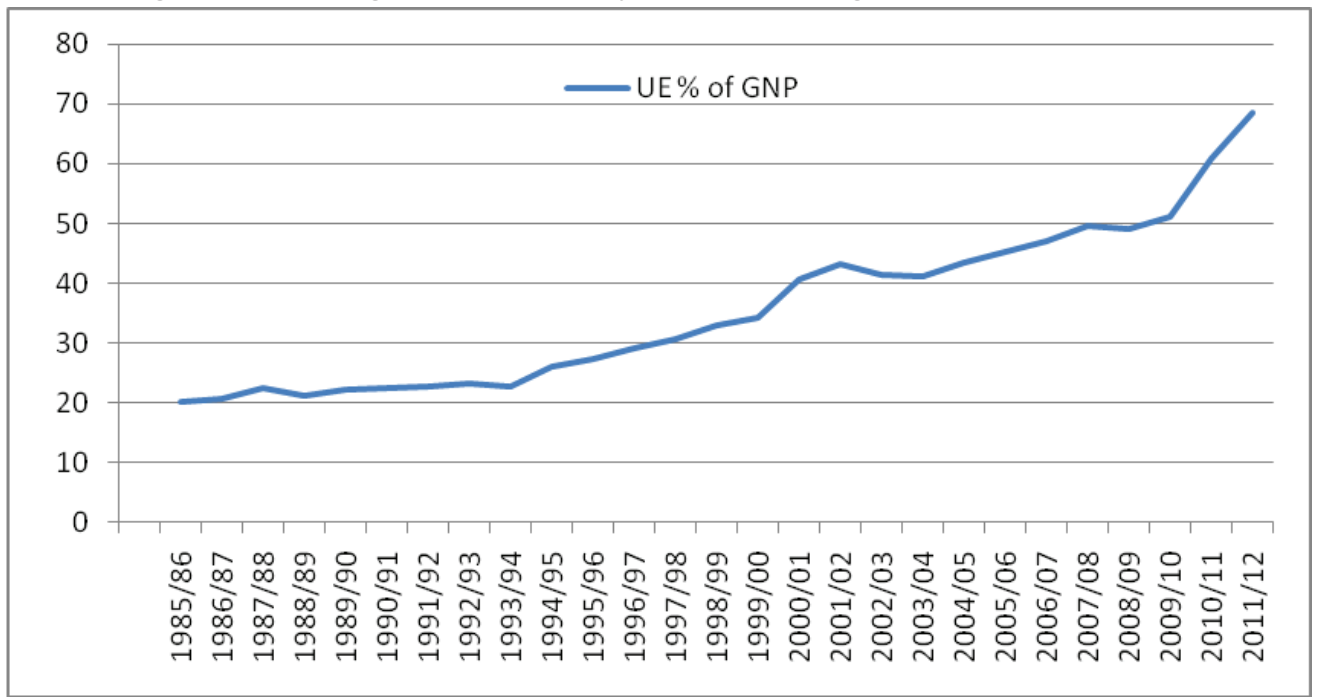

Source: Author's estimation. 
The UE remained within 20 to 30 percent between FY 1986 and FY 1997,that is, it took almost a decade for UE to increase by almost 10 percentage points (roughly speaking, about 1 percentage point in a year). However, after the year 1997 which is also marked as the beginning of the armed conflict in Nepal, the extent of UE increased by same percentage points (i.e., from 30 percent to 40 percent) but only in five years' time period (say about 2 percentage point in a year).

Interestingly again, the increment in the extent of UE in the last one decade slowed down meaning that it again took almost 10 years from FY 2001 to 2010 for a 10 percentage points increase (from about 40 percent to 50 percent i.e. again about 1 percentage point a year).This might imply that, in the beginning years of the armed conflict, the new recruitments and the bulk purchase of the arms and ammunitions and other logistics might have been largely financed from illegal money. There were also several cases of corruption involving large chunk of money with the involvement of big politicians and bureaucrats. However, coming to the last one decade, although the extent of UE has been increasing, the increment has been slow. This may be because there were several failed attempts made to hold peace talks between the armed forces and the Government which at times may have slowed the pace of new recruitment and purchases of arms and ammunition. Since 2006 after signing the CPA with the government, this phenomenon virtually stopped. Moreover, since the year 2000 the anti corruption campaign in Nepal has become stronger. This was partly due to the provocative work of the CIAA, but also due to the rising awareness of the people, and pressure from civic-minded factions of Nepalese society and donor countries. King Gyanendra formed The Royal Commission for Corruption Control (RCCC) in 2005 after he took over the absolute power dismissing the Sher Bahadur Deuba's Government. The Commission could seize property amassed through abuse of authority, tax evasion or smuggling, illegal contracts and other actions defined as corruption by court. It had all the powers of the court. Several high profile politicians and bureaucrats were taken action and punished when found guilty. This also might have helped slowed down the economic crimes during the last one decade.

Surprisingly, the economy saw an almost 18 percentage point increase in the extent of UE (as a \% of GNP) only in two years time period i.e. in 2011 and 2012. In 2011, the UE as a percentage of GNP has been 60.76 percent - which is about a 10 percentage point increase from the FY 2010 and in 2012, the same has been 68.44 - which is again an increase of about 8 percentage points. There may be several reasons for such an 
upsurge in the last two years. First, various study on black economy of India measures its extent from 50 to 70 percent of GDP. As such it is not unsurprising for Nepal which shares 1850 kilometers long border with India to have such a larger extent of UE. Second, the declining growth rates of tax revenue more importantly income taxes and custom duty in the last few years further prove that there have been large numbers of cases of tax evasions. A recent fake VAT bill fraud worth Rs 3.06 billion and the whopping 178 cases of banking crimes worth Rs 10 billion further substantiate this fact (Republica, 2013). Third, growing extent of informal sector in recent years also justifies the prevalence of such a huge extent of UE. Finally, the growth in government corruption, the prevalence of large scale cash economy, open border with India, poor regulation of trade and financial sector regulation might have added to such as alarming growth of the degree of black economy in Nepal.

\section{CONCLUSION}

We find that the growth rate of revenue has increased up to fiscal year 2009 and have fallen sharply thereafter indicating that the extent of UE has drastically increased in recent years. This is also indicated by the fact that the growth rate of tax revenue reduced from 17.11 percent during 1991-2001 to 16.65 percent during 2002-2011. Moreover the growth rate of the custom duty and income tax reduced by 4.82 and 12.06 percentage points respectively during these time periods. This evidence might also suggest that taxpayers have been proportionately evading more income taxes than the custom duties in recent years. The Inland Revenue Department determined the income tax worth Rs. 3.32 billions and excise duty worth Rs. 205.27 million to be recovered from the tax evaders for the fiscal year 2010 the total of which accounts for about 5 percent of GDP for the same fiscal year. Consequently, our empirical results suggest that there has been a phenomenal growth of underground economy in the recent decades with an unexpected 'upsurge' in the last few years. The growth rate had been 19.21 percent between 1991 and 2000; 16.68 percent between 2001 and 2010; and 31.7 percent between 2011 and 2012.

In order to control UE, the government has been enacting several stringent rules and regulations and establishing the institutional arrangements required thereof time and again. The most important one among them recently introduced is the Anti money laundering Act 2008 and the establishment of Department of Money Laundering Investigation (DMLI). The concerned authorities have been working hard to strengthen the DMLI. Often politicians and even high level responsible officers are 
found involved in UE. These people are generally not taken any action because of the protection extended by different political parties and leaders. This tends to foster the violation of law and order in the country and even act as an incentive to others to engage in such activities. The proposed AML Act in its full fledged form has provision to increase the scrutiny of financial position of politically exposed persons (PEPs) which is in line with the FATF's revised recommendation in $2012^{5}$. The work is in progress to expand the PEPs' list. Hence, it is high time for the government of Nepal to give due importance to the issues of UE. Provisions of efficient and effective labor market regulation, cut-off of extra burden of formal sector; may it be high tax rate, tough formalities or any, punishment and reward system could help minimize size of UE in days to come. Moreover, high tax rates imposed by government on formal sectors also supports informal economy. Also it is important to provide better social security and protection to the tax payers and general public which discourages people to undertake illegal economic activities. Better provision of public good and services by increasing their quality and quantity will also help discourage people to conduct economic crimes. Similarly, the long run market based reforms, including fiscal reforms, along with improved governance and stronger institutions are effective ways of reduce the size of UE in Nepal. Unless economic agendas are not given topmost priority by the statesmen, UE in Nepal is bound to increase.

Acknowledgement: The authors would like to acknowledge the University Grants Commission (UGC) Nepal for providing the Faculty Research Grant for this study. We would also like to thank Mr. Birendra Budha and Mr. Guna Raj Bhatta at Nepal Rastra Bank for the insightful comments to improve on the paper so far possible.

${ }^{5}$ PEPs are the persons who have hold the position above the secretary level in government offices. 


\section{Appendix 1}

\section{Diagnostics of the Model}

\section{a) LM Test}

Figure 1 : The residual plot of Equation 4

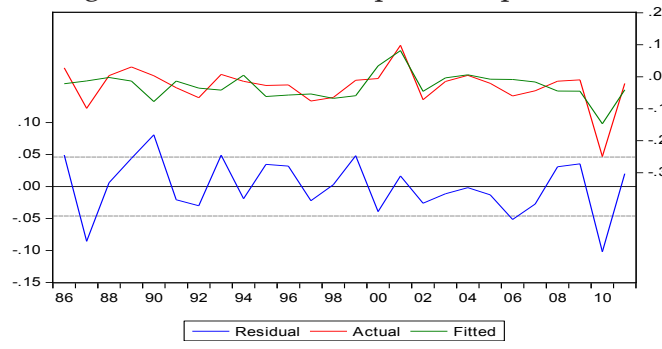

b) CUSUM and CUSUMSQ Test
Figure 2 : The residual plot of Equation 5

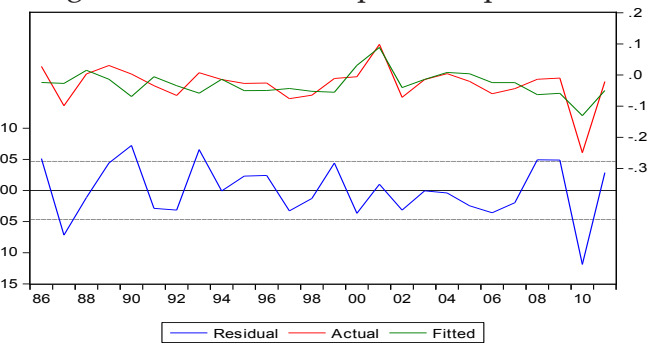

Figure 3 : CUSUM and CUSUM of Squares Test for Equation 4
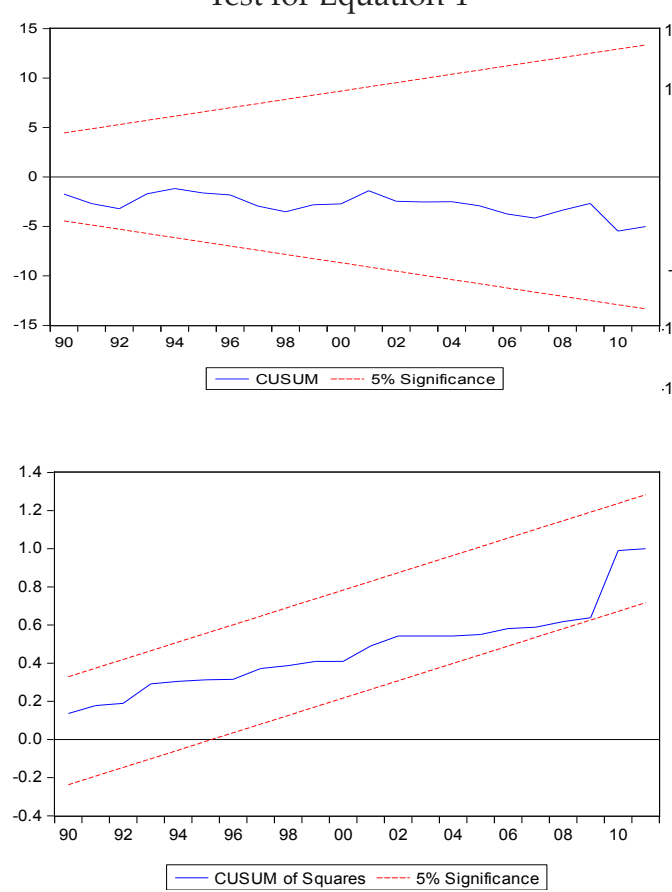

Figure 4 : CUSUM and CUSUM of Squares Test for Equation 5

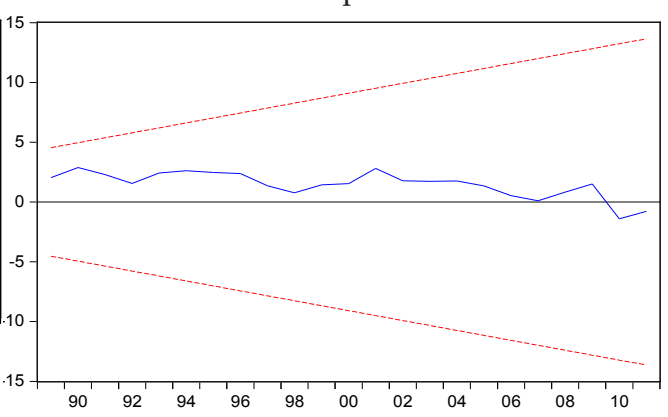

- CUSUM ----. $5 \%$ Significance

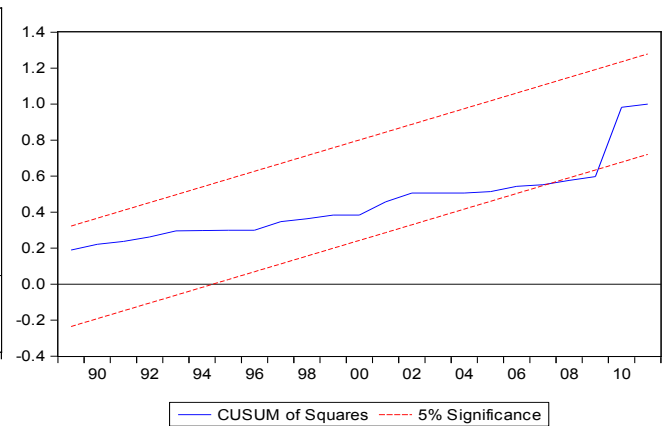




\section{Appendix 2}

Augmented Dickey Fuller Test

\begin{tabular}{lllllll}
\hline \multirow{2}{*}{ Variable } & \multicolumn{2}{l}{ Level } & \multicolumn{2}{l}{ First Difference } & \multicolumn{2}{l}{ Second Difference } \\
\cline { 2 - 6 } & t-stat & P-value & t-stat & P-value & t-stat & P-value \\
\hline $\ln C / \mathrm{M} 2$ & 0.706288 & 0.9899 & $-5.443881^{*}$ & 0.0002 & & \\
$\ln C O N S M / Y$ & $-4.103694^{*}$ & 0.0057 & & & & \\
$\ln \mathrm{N}$ & -1.361763 & 0.5850 & $-4.513537^{*}$ & 0.0016 & & \\
$\ln \mathrm{T} / \mathrm{Y}$ & 0.405933 & 0.9793 & $-4.107932^{*}$ & 0.0041 & & \\
$\ln \mathrm{Y} / \mathrm{N}$ & 1.766677 & 0.9994 & -0.631811 & 0.8462 & $-5.670958^{*}$ & 0.0001 \\
$\ln \mathrm{NNF}$ & -2.496773 & 0.1277 & $-6.056915^{*}$ & 0.0000 & & \\
\hline
\end{tabular}

Note: * Stationary at $5 \%$ or lower level of significance, that is, stationary.

Source: Authors' estimation.

\section{Appendix 3}

\section{Regression Result for the Full Model}

Dependent Variable: First Difference logs C/M2

\begin{tabular}{lccc}
\hline \multicolumn{1}{c}{ Variables } & Coefficient & t-stat & p-value \\
\hline $\ln (\mathrm{CONSM} / \mathrm{Y})$ & 0.5572 & 1.521223 & 0.1447 \\
$\Delta \ln (\mathrm{R})$ & -0.2194 & -3.562444 & 0.0021 \\
$\Delta \ln (\mathrm{T} / \mathrm{Y})$ & 0.1435 & 0.881272 & 0.3892 \\
\multicolumn{1}{c}{$\Delta(\Delta \ln (\mathrm{Y} / \mathrm{N}))$} & 0.0381 & 0.135243 & 0.8938 \\
$\Delta \ln (\mathrm{INF})$ & 0.0062 & 0.204888 & 0.8398 \\
Constant & 0.1057 & 1.132819 & 0.2714
\end{tabular}

R-Squared=0.5306 ; Adjusted R-Squared=0.4071 ; F-stat $=4.2960$; Prob(F-stat) $=0.0087$; DurbinWatson stat $=2.4208$

Source: Authors' estimation. 


\section{Appendix 4}

Size of Underground Economy (UE) in Nepal, 1985/86-2011/12

(amount in Rs. millions)

\begin{tabular}{ccccccccc}
\hline FY & M1 & M2 & GNP & IM & LM & $\begin{array}{c}\text { Velocity } \\
\text { (times) }\end{array}$ & UE & $\begin{array}{c}\text { UE \% of } \\
\text { GNP }\end{array}$ \\
\hline $1985 / 86$ & 7029 & 15159 & 56443 & 1175.66 & 5854 & 10 & 11336.17 & 20.08 \\
$1986 / 87$ & 8120 & 17498 & 65067 & 1386.74 & 6733 & 10 & 13400.39 & 20.59 \\
$1987 / 88$ & 9597 & 21423 & 78481 & 1754.65 & 7842 & 10 & 17560.29 & 22.38 \\
$1988 / 89$ & 11775 & 26605 & 90811 & 2054.82 & 9721 & 9 & 19196.47 & 21.14 \\
$1989 / 90$ & 14223 & 31552 & 105350 & 2579.65 & 11643 & 9 & 23340.85 & 22.16 \\
$1990 / 91$ & 16284 & 37713 & 122517 & 2987.69 & 13296 & 9 & 27530.44 & 22.47 \\
$1991 / 92$ & 19458 & 45671 & 152202 & 3599.47 & 15858 & 10 & 34546.54 & 22.70 \\
$1992 / 93$ & 23833 & 58323 & 174705 & 4474.69 & 19358 & 9 & 40383.20 & 23.12 \\
$1993 / 94$ & 28510 & 69777 & 203135 & 5258.59 & 23252 & 9 & 45940.62 & 22.62 \\
$1994 / 95$ & 32985 & 80985 & 223992 & 6790.76 & 26195 & 9 & 58068.17 & 25.92 \\
$1995 / 96$ & 36498 & 92652 & 252479 & 7793.61 & 28704 & 9 & 68551.32 & 27.15 \\
$1996 / 97$ & 38460 & 103721 & 285173 & 8636.29 & 29824 & 10 & 82578.96 & 28.96 \\
$1997 / 98$ & 45164 & 126463 & 306870 & 10553.28 & 34611 & 9 & 93569.39 & 30.49 \\
$1998 / 99$ & 51063 & 152800 & 352917 & 12612.62 & 38450 & 9 & 115766.53 & 32.80 \\
$1999 / 00$ & 60980 & 186121 & 392613 & 15551.19 & 45429 & 9 & 134400.22 & 34.23 \\
$2000 / 01$ & 70577 & 214454 & 443220 & 20369.62 & 50207 & 9 & 179818.48 & 40.57 \\
$2001 / 02$ & 77156 & 223988 & 458838 & 23201.45 & 53955 & 9 & 197308.07 & 43.00 \\
$2002 / 03$ & 83754 & 245911 & 491555 & 24535.80 & 59218 & 8 & 203664.98 & 41.43 \\
$2003 / 04$ & 93974 & 277310 & 535065 & 27308.46 & 66665 & 8 & 219181.68 & 40.96 \\
$2004 / 05$ & 100206 & 300440 & 591048 & 30261.85 & 69944 & 8 & 255722.02 & 43.27 \\
$2005 / 06$ & 114389 & 347422 & 659040 & 35643.36 & 78745 & 8 & 298308.05 & 45.26 \\
$2006 / 07$ & 126888 & 395518 & 735259 & 40506.62 & 86381 & 9 & 344783.24 & 46.89 \\
$2007 / 08$ & 154344 & 495377 & 823605 & 51061.01 & 103283 & 8 & 407173.99 & 49.44 \\
$2008 / 09$ & 196459 & 630521 & 1000021 & 64672.88 & 131787 & 8 & 490750.08 & 49.07 \\
$2009 / 10$ & 218159 & 719599 & 1201891 & 73678.68 & 144480 & 8 & 612912.17 & 51.00 \\
$2010 / 11$ & 223075 & 922044 & 1382503 & 84310.61 & 138764 & 10 & 839984.43 & 60.76 \\
$2011 / 12$ & 264373 & 1130970 & 1550785 & 107422.49 & 156951 & 10 & 1061412.17 & 68.44 \\
\hline
\end{tabular}

Note: FY=Fiscal Year, GNP=Gross National Product, M1=Narrow Money Supply, M2=Broad Money Supply, IM=Illegal Money, LM=Legal Money, M1=Narrow Money Supply, M2=Broad Money Supply, UE=Underground Economy

Source: M1,M2, and GNP figures are taken from Economic Survey(several issues) published by Ministry Finance of the Government of Nepal, and Quarterly Economic Bulletin(Several issues) of Nepal Rastra Bank, and other figures are estimated by the authors. 


\section{References}

Adam, M. C., \& Ginsburgh, V. (1985). The effects of irregular markets on macroeconomic policy: Some estimates for Belgium. European Economic Review, 29(1), 15-33.

Arby, M. F., Malik, M.J. \& Hanif, M.N. (2010). The size of informal economy in Pakistan. SBP Working Paper No. 33.

Ariyo, A., \& Bekoe, W. (2012). Currency demand, the underground economy and tax evasion: The case of Nigeria. Journal of Monetary and Economic Integration, 11(2), 129-157.

Asaminew, E. (2010). The underground economy and tax evasion in Ethiopia: Implications for tax policy. Ethiopian Economic Policy Research Institute (EEPRI)/ Ethiopian Economic Association (EEA).

Asea, P. K. (1996). The informal sector: Baby or bath water? Carnegie-Rochester Conference Series Public Policy, 45, 163-71.

Becker, G. S. (1968). Crime and punishment: An economic approach. Journal of Political Economy, 76(2), 169-217.

Brown, R.L., Durbin, J. \& Evans, J.M. (1975). Techniques for testing for the constancy of regression relationships over time. Journal of the Royal Statistical Society. Series B (Methodological), 37, 149-192.

Cagan, P. (1958). The demand for currency relative to the total money supply. Journal of Political Economy, 66, 302-328.

Chaudhury, K., Schneider, F. \& Chattopadhyay, S. (2006). The size and development of the shadow economy: An empirical investigation from states of India. Journal of Development Economics, 80, 428-443.

Choi, J.P. \& Thum, M.P. (2002). Corruption and the shadow economy. CESIFO Working Paper Series No. 633.

Dickey, D. A., \& Fuller, W. A. (1979). Distribution of the estimators for autoregressive time series with a unit root. Journal of the American Statistical Association, 74, 427-431.

Dickey, D. A., \& Fuller, W. A. (1981). Likelihood ratio statistics for autoregressive time series with a unit root. Econometrica, 49, 1057-1072.

Dreher, A. \& Schneider, F. (2006). Corruption and the shadow economy: An empirical analysis. IZA Discussion Papers No. 1936

Dutta, N., Kar, S., \& Roy, S. (2011). Informal sector corruption: An empirical investigation for India. IZA Discussion Papers No. 5579 
Eilat, Y., \& Zinnes, C. (2000). The evolution of the shadow economy in transition countries: Consequences for economic growth and donor assistance. CAER II Discussion Paper No. 83. HIID

Feige, E.L. (1997). Revised estimates of the underground economy: Implications of US currency held abroad. Retrieved from http://oldfraser.lexi.net/publications/ books/underground/section_3.html

Filmer, R. (2003). South Asia FDI roundtable, FIAS-International Finance Corporation,Washington,D.C.

Ghimire, B. (2006). Study for the measures of tax compliance habit and leakage control. Economic Policy Network, GON/MOF, Kathmandu, Nepal

Gills, D. (1998). Measuring the size of the hidden economy: Implications for econometric modeling. Econometrics Working Paper No. 9809.

Johansen, S. (1988). Statistical analysis of cointegration vectors. Journal of Economic Dynamics and Control, 12,, 231-254.

Johansen, S., \& Juselius, K. (1990). Maximum likelihood estimation and inference on cointegration-with applications to the demand for money. Oxford Bulletin of Economics and Statistics, 52, 169-210.

Katsios, S. (2006). The shadow economy and corruption in Greece. South-Eastern Europe Journal of Economics, 1, 61-80.

King, J., Holland, G., Goorman, A. \& Hansen, D. (2003). Nepal: Next steps in tax reform. IMF Technical Assistance Report.

Loayza, N. V. (1996). The economics of the informal sector: A simple model and some empirical evidence from Latin America. Carnegie-Rochester Conference Series Public Policy, 45, 129-62.

Mirus, R. \& Smith, R.S. (1997). Canada's underground economy: Measurement and implications. In O. Lippert and M. Walker (Eds.). The underground economy: Global evidence of its size and impact. Vancouver: Fraser Institute.

MOF.(2011). Annual progress report 2011. Kathmandu: Ministry of Finance, Government of Nepal.

Ogunc, F. \& Yilmaz, G. (2000). Estimating the underground economy in Turkey. Research Department Discussion Paper, The Central Bank of the Republic of Turkey.

Pesaran, M. H., \& Shin, Y. (1999). An autoregressive distributed lag modelling approach to cointegration analysis. In S. Strom (Ed.). Econometrics and economic theory in the 20th Century: The Ragnar Frisch centennial symposium. Cambridge University Press, Cambridge. 
Pesaran, M. H., Shin, Y. \& Smith, R.J. (2001). Bounds testing approaches to the analysis of level relationships. Journal of Applied Econometrics, 16, 289-326.

Porqueras, P.G., Alva, A.P., \& Waller, C.J. (2011). Quantifying the shadow economy: Measurement with Theory. Research Division, Federal Reserve Bank of St. Louis

Pyakuryal, B., Dahal, M.K., Nepal, G., Adhikari, D. \& Gautam, G. (2009). Fiscal management and revenue sharing in Nepal. Nepal Economic Association.

Rajkarnikar, P. (2006). Implementation of the WTO customs valuation agreement in Nepal: An ex-ante impact assessment. Working Paper Series No. 18, UNESCAP/ARTNet

Republica. (2013). Financial crime mind-boggling; Rs 10b embezzled. My Republica Daily, 7th March, 2013. Available at http://www.myrepublica.com/portal/index. php?action=news_detailsandnews_id=51093).

Schneider, F., \& Enste, D.H. (2000). Shadow Economies: Size, Causes, and Consequences. Journal of Economic Literature, 38, 77-114.

Schneider, F \& Enste, D.H. (2002). The shadow economy. An international survey. Cambridge: Cambridge University Press.

Schneider, F., A. Buehn, A. \& Montenegro, C.E. (2010). Shadow economies all over the world: New estimates for 162 countries from 1999 to 2007.(Policy Research Working Paper No 5356).Washington DC: The World Bank.

Tanzi, V. (1980). The underground economy in the United States: Estimates and implications. Banca Nazionale del Lavoro, 135, 427-53.

Tanzi, V. (1982). A second (and more skeptical) look at the underground economy in the United States. In Tanzi, V. (Ed.). The underground economy in the United States and abroad (pp.38-56). Lexington (Mass.), Lexington.

Tanzi, V. (1983).The underground economy in the United States: Annual estimates, 1930-1980.Staff Papers IMF, 30(2), 283-305.

Torgler, B., \& Schneider, F. (2007). The impact of tax morale and institutional quality of the shadow economy. CREMA Working Paper Series 2007-01. 